\title{
Az önkéntes véradás hazai médiareprezentáció- jának empirikus vizsgálata egyetemi hallgatók mintáján
}

\author{
Dorner László \\ Eszterházy Károly Egyetem
}

\section{A TANULMÁNY CÉLJA}

Az önkéntes véradás hazai kommunikációs és médiareprezentációjának vizsgálata: milyen platformokon, milyen idöközönként találkoznak a témával az egyetemi hallgatók, mennyire hatékonyan szólítják meg őket a jelenlegi toborzási módszerek, platformok, reklámok, a személyt körülvevő társas kapcsolati háló. Ezen kívül a véradással kapcsolatos tudnivalók ismerete is vizsgálatunk tárgyát képezte.

\section{ALKALMAZOTT MÓDSZERTAN \\ Véradó ( $N=250)$ és nem véradó ( $N=262)$ felsőoktatásban tanuló hallgatók vettek részt korábbi nemzetközi kutatásokban (Zito et al 2012) használt, valamint saját szerkesztésủ önkitöltős kérdőívekkel végzett vizs- gálatunkban.}

\section{LEGFONTOSABB EREDMÉNYEK}

A társas kapcsolatok mind a véradók, mind a nem véradók megszólításában kiemelt jelentőséggel bírnak: a szülők és barátok mellett az aktív véradók meggyőzésben betöltött szerepét emelhetjük ki. Az információszerzésben az internetes médiafelületek és a nyomtatott sajtótermékek, a kampányelemeknél a személyes példamutatás és a gondolkodásra késztető üzenetek hatékonysága mutatható ki. A korrekt tájékoztatás (a véradás feltételeiről, folyamatáról és a kizárás okairól) és a személyzet empatikus hozzáállása, kommunikációs készsége egyértelmüen hozzájárulhatnak a véradás elkezdéséhez.

\section{GYAKORLATI JAVASLATOK}

Az aktív véradók toborzásban betöltött szerepének növelése, a fiatalok igényeihez illesztett, főként digitális térben megvalósuló, folyamatos információáramlást biztosító, dinamikus marketing- és kommunikációs stratégia alkalmazása javíthatja a célcsoport toborzásának és megtartásának hatékonyságát.

Kulcsszavak: önkéntes véradás, médiareprezentáció, kommunikáció, marketing, internet

Köszönetnyilvánitás: Köszönöm a Magyar Vöröskeresztnek a kutatásban nyújtott segítségét.

DOI: 10.15170/MM.2020.54.04.02 


\section{BEVEZETŐ - MIÉRT FONTOS A VÉRADÁS? \\ INTRODUCTION - WHY BLOOD DONATION IS IMPORTANT}

Titmuss (1970) szerint az önkéntes véradás talán a legtisztább példája az altruizmusnak, a mások érdekében történő önzetlen cselekvésnek: egy saját elhatározáson alapuló, évente többször megismételhető proszociális viselkedésforma, amelyért közvetlen anyagi ellenszolgáltatásban nem részesül a donor (Mathew et al. 2007). Hazánkban évente 390 ezer egység vérre van szükség a biztonságos vérellátáshoz (veradas.hu). A véradó bázis egyre idősebb: jelenleg a mai 40-es, 50-es korosztály véradási aktivitásának, illetve az újonnan bevont fiatal felnőtt személyeknek (Béla-Csovcsics és Kincsesné 2018) köszönhetjük a vérkészlet meghatározó hányadát.

A felsőoktatási hallgatók toborzása és megtartása kulcstényezőnek tekinthető a jövőbeli biztonságos vérellátottság szempontjából: az átlagosnál jobb egészségmutatókkal rendelkező korosztályról beszélünk, ugyanakkor a kizárás kritériumai (piercing, szexuális partnerek gyakori cserélése) gyakrabban okoznak problémát (Misje et al. 2005).

\section{A VÉRADÁS SZOCIOKULTURÁ- LIS HATÁSRENDSZERE THE SOCIOCULTURAL BACK- GROUND OF BLOOD DONATION}

Korábbi kutatások (Godin et al. 2007, Royse és Doochin 1995, Quéniart 2013) rámutattak, hogy nagyobb eséllyel adnak vért azok a személyek, akiknek a társas hálója véradókat is magában foglal, különösen a család szocializációs szerepe emelhető ki. Gillespie és Hillyer (2002) szerint a véradók $75 \%$-ának valamely családtagja vagy barátja legalább egyszer adott vért életében, míg egy másik kutatás (Nilsson et al. 2007) szerint az első véradók 47\%-a baráti hatásra adott vért. Az interperszonális kapcsolati hálóink lehetőséget teremtenek arra, hogy a véradással kapcsolatos tapasztalatainkat megosszuk másokkal: a közösség által az egyénre gyakorolt befolyásként vagy a véradásra bátorító szocializációs ágensként egyaránt hathatnak (Abril 2016).

\section{A VÉRADÁS MÉDIAKOMMUNI- KÁCIÓJA BLOOD DONATION IN THE MEDIA}

A hatékony kommunikációs stratégiák alkalmazása az önkéntes véradók toborzásának nélkülözhetetlen eleme, melyben a tömegkommunikáció és a személyközi kommunikáció szerepe egyaránt kiemelhető (Abril 2016). Számos kutatás (Abril 2016, Godin et al. 2011) alapján úgy tünik, a véradásról való személyközi (face to face) kommunikáció egyértelmüen növeli a jövőbeli véradás esélyét. Ennek magyarázata lehet, hogy aktív, kétoldalú kommunikációt tesz lehetővé (Wakefield et al. 2010). A tömegkommunikációs eszközök jelentősége kiemelt a megszólításban (Muthivni et al. 2015), azonban az így elért véradók megtartása kihívásteli feladat (Misje et al. 2005, Rojas \& Abril 2006). A közösségi médiafelületek az egészségügyi rendszer különböző szegmenseiben, beleértve a véradás promócióját is, egyre nagyobb részt vállalnak, a felhasználók egyre gyakrabban használják ezen felületeket (pl. Twitter, Facebook) a vérszükséglet célzott és minél gyorsabb kielégítésére (Abbasi et al. 2018). Agrawal et al. (2013) vizsgálatukban az elektronikus médiafelületek kiemelt szerepét mutatták ki a véradással kapcsolatos információkhoz való hozzájutásban.

\section{A VÉRADÁSSAL KAPCSOLATOS ISMERETEK SZEREPE THE ROLE OF INFORMATION ABOUT BLOOD DONATION}

Bettinghaus és Milkovich (1975) egy korai kutatásukban azt találták, hogy a véradók és a nem véradók véradási folyamattal kapcsolatos ismeretei, valamint ezen ismeretek tömegkommunikáció általi elérése terén nem mutattak számottevő különbséget. A nem véradók a barátoktól gyakrabban szereztek információkat, mint a véradók, és a donortoborzásban kiemelt jelentőségű volt a személyes meggyőzés. Al-Drees (2008) szerint mind a véradók, mind a nem véradók egy része hiányos ismeretekkel bír a véradással kapcsolatos ismeretek terén. Kurrens kutatások (Dadwani et al. 2019, Moore et al. 2020) alapján az egyetemisták 50-60 \%-a rendelkezik megfelelő ismeretekkel a véradásról. Tadesse et al. (2018) kutatásukban rávilágítottak arra, hogy az ilyen ismeretekkel inkább rendelkező egyetemisták kedvezőbb attitűddel rendelkeztek a véradás iránt, Bednall és Bove (2011) 
szerint pedig a véradás elkerüléséhez a véradással kapcsolatos ismeretek hiánya is hozzájárulhat.

France et al. (2010) eredményei szerint azok a személyek, akiknek a véradó központ információs kiadványokat és emlékeztetőket (pl. a véradás folyamatáról és az aktuális vérkészletről) biztosított a véradás előtt, nagyobb valószínúséggel jelentek meg a következő véradáson, mint azok a személyek, akik csak egy általános reklámanyagot kaptak. Az első véradók megszólításában az információs szóróanyag és a telefonos emlékeztető kombinációja (Masser et al. 2016), gyakorlott véradóknál ellenben az emailes és a telefonos emlékeztető kombinációja bizonyult a leghatékonyabbnak (Germain és Godin 2016).

\section{AZ EMPIRIKUS KUTATÁS THE EMPIRICAL STUDY}

\section{A kutatás céljai és hipotézisei Aims and hypotheses of the research}

A kutatás célja, hogy megvizsgálja az önkéntes véradás médiareprezentációját: milyen platformokon, milyen időközönként találkoznak a témával, a jelenlegi toborzási módszerek, reklámok menynyire hatékonyan szólítják meg a jelenlegi egyetemista korosztályt. A célcsoport kiválasztását az indokolta, hogy a véradó bázis megújulása szempontjából kulcsfontosságú korcsoportról beszélünk, amely fokozottan hajlamos lemorzsolódásra az első véradást követően (Godin et al. 2007). A fiatal véradókra tehát kiemelt figyelmet kell fordítanunk, ha szeretnénk segíteni őket a sokszoros véradóvá válásban, melynek első lépése a véradással kapcsolatos ismereteik, attitüdjeik, élményeik vizsgálata. Ezen kívül arra is kitérünk, hogy az egyetemista korosztály tagjai számára a környezetükben élő személyek közül kik gyakorolták a legjelentősebb hatást arra, hogy elkezdjenek vért adni, valamint hogy a véradással kapcsolatos alapvető ismeretekkel mennyire vannak tisztában a vizsgálati személyek. Végül rákérdeztünk arra is, milyen tényezők segíthetnék azt, hogy egy egyetemista hallgató véradóvá váljon.

A korábbi kutatási eredmények ( $\mathrm{pl}$. Agrawal et al. 2013, Alessandrini 2007) alapján az alábbi hipotéziseket állítottuk fel:

H1: Az aktivv véradók szülei és barátai között több véradót találunk, mint a nem véradók között.

H2: A véradással kapcsolatos ismeretek többségével a véradók szignifikánsan jobban tisztában vannak.
H3: A nem véradók számára a véradással kapcsolatos ismeretek nyújtása és a társas támogatás érzése kiemelt jelentöséggel bír.

H4: A véradással kapcsolatos információk leghatékonyabban az interneten keresztül jutnak el a potenciális véradókhoz.

\section{A kutatás mintája Sample}

A szociodemográfiai szempontból széleskörü adatfelvétel érdekében online platformokon (pl. a Magyar Vöröskereszt Facebook csoportja) toboroztuk a vizsgálati személyeket. Az ország 29 felsőoktatási intézményéből és 30 különböző szakjáról összesen 512 fő (250 fő véradó és 262 fö nem véradó) nappali és levelező tagozaton tanuló hallgató alkotta a mintát, a vizsgálati szempontból nem megfelelő adatközlők (pl. már nem rendelkezik hallgatói státusszal) és a hiányos kitöltők (pl. nem fejezték be a kérdőív kitöltését) kizárása után. Számos kérdés tekintetében lehetővé vált a véradók és a nem véradók által adott válaszok szisztematikus összehasonlítása. Az 1. táblázat részletesen bemutatja, hogy a két alminta szociodemográfiai mutatói (lakhely, képzési szint) a nem kivételével nem mutattak jelentős különbséget. 
1. táblázat: A minta szociodemográfiai megoszlása $(\mathrm{N}=512)$

Table 1. Demographic data of respondents $(\mathrm{N}=512)$

\begin{tabular}{|c|c|c|c|}
\hline & $\begin{array}{l}\text { Véradó } \\
(\mathrm{N}=\mathbf{2 5 0})\end{array}$ & $\begin{array}{c}\text { Nem véradó } \\
(\mathrm{N}=262)\end{array}$ & Összesen \\
\hline \multicolumn{4}{|l|}{ Nem } \\
\hline Férfi & 80 & 36 & 116 \\
\hline Nő & 170 & 226 & 396 \\
\hline Életkor (év, átlag, szórás) & $24,05(\mathrm{SD}=5,04)$ & $22,85(\mathrm{SD}=4,29)$ & \\
\hline \multicolumn{4}{|l|}{ Lakhely } \\
\hline $\begin{array}{l}\text { Község } \\
\text { Megyeszékhely, m.j.v. } \\
\text { Egyéb város } \\
\text { Főváros }\end{array}$ & $\begin{array}{l}64 \\
78 \\
64 \\
42 \\
\end{array}$ & $\begin{array}{l}52 \\
88 \\
87 \\
35\end{array}$ & $\begin{array}{c}116 \\
166 \\
151 \\
77\end{array}$ \\
\hline \multicolumn{4}{|l|}{ Képzési szint } \\
\hline $\begin{array}{l}\text { FOSZ } \\
\text { Alapképzés } \\
\text { Mesterképzés } \\
\text { Egységes osztatlan k. } \\
\text { Posztgraduális }\end{array}$ & $\begin{array}{c}10 \\
152 \\
41 \\
36 \\
4 \\
\end{array}$ & $\begin{array}{c}13 \\
147 \\
29 \\
62 \\
5\end{array}$ & $\begin{array}{c}23 \\
299 \\
70 \\
98 \\
9 \\
\end{array}$ \\
\hline \multicolumn{4}{|l|}{ Végez-e önk. munkát? } \\
\hline $\begin{array}{l}\text { Igen, jelenleg is } \\
\text { Igen, régebben } \\
\text { Nem, de tervezi } \\
\text { Nem, és nem is gondolt rá }\end{array}$ & $\begin{array}{c}54 \\
75 \\
1 \\
119\end{array}$ & $\begin{array}{c}51 \\
112 \\
1 \\
97\end{array}$ & $\begin{array}{c}105 \\
187 \\
2 \\
216\end{array}$ \\
\hline
\end{tabular}

Forrás: saját szerkesztés

\section{Anyag és módszer Methodology}

Online önkitöltős kérdőívet készítettünk egy korábbi olasz (Zito et al. 2012) nyelvterületen született kutatás egyes tételeinek felhasználásával. $\mathrm{Az}$ eredeti vizsgálat serdülőkorú, nem véradó mintával dolgozott, így célcsoportunk vizsgálata érdekében minimális nyelvi-stilisztikai és tartalmi változtatásokat eszközöltünk. Minden esetben az itemek fordítása és visszafordítása, majd korrekciója előzte meg a mérőeszközök alkalmazását. Valamennyi kérdésnél szakmai egyeztetés keretében kikértük véradásszervezésben dolgozó (Magyar Vöröskereszt, OVSZ), és aktív véradó személyek véleményét a teszteléskor, hogy akad-e olyan tétel, ami nem érthetö, vagy esetleg hiányzik a felsorolásból, de fontos lehet, ezek alapján néhány helyen kibővítettük a válaszlehetőségeket (pl. a véradással kapcsolatos ismereteket saját szerkesztésủ kérdésekkel mértük). Az adatfelvétel online környezet- ben (UNIPOLL), két részletben zajlott 2018 februárja és 2019 februárja között (először a véradó, majd a nem véradó mintán), egy-egy résztvevő esetében 30-35 percet vett igénybe. A kérdöív dichotóm kérdéseket (pl. „Részt vettél-e már legalább egy alkalommal önkéntes véradáson?") és 5 fokú Likert típusú skálákat (pl. „Milyen gyakran találkozol a véradás témájával az alábbi kommunikációs csatornákon?") tartalmazott.

A kérdőív egyes részei csak nem véradók számára (pl. véradásra irányuló döntést elösegítő tényezők), másik része csak véradók számára volt kitölthető (pl. a véradás elkezdésére hatást gyakorló személyek), míg a többi kérdést mindkét csoport tagjai kitöltötték (pl. véradó ismerősök száma, a véradással kapcsolatos ismeretek megléte, bizonyos helyzetek mozgósító hatásának, a véradással kapcsolatos ösztönzőknek a megítélése). A vizsgálataink eredményeit a későbbiekben leíró statisztikákra (khí-négyzet próbák, független mintás t-próbák) támaszkodva mutatjuk be. 


\section{A kutatás eredményei Results}

A véradás szociokulturális hatásrendszere The sociocultural background of blood donation

A véradás szempontjából meghatározó tényező lehet, hogy a személy ismer-e véradókat a környezetében. Khí-négyzet próbával ismerőstípusonként megvizsgáltuk, találunk-e különbséget a véradók és a nem véradók között a véradó ismerősök tekin- tetében, azonban egyetlen kategóriában sem találtunk szignifikáns különbséget a két csoport között. Ahogy az 1. ábrán látható, mind a véradók, mind a nem véradók $60-70 \%$-a rendelkezik véradó baráttal, de véradó hallgatótársat is a minta több mint fele ismer. Kisebb számban (30-35\%) a szülők és más rokonok között is találhatunk véradókat, oktatókat a minta negyede ismer. Örvendetesen kevesen $(<10 \%)$ vannak mindkét csoportban, akik egyáltalán nem ismernek véradókat.

1. ábra: Véradó ismerősök százalékos aránya $(\mathrm{N}=512)$

Figure 1. Percentage of blood donors among acquaintances $(\mathrm{N}=512)$

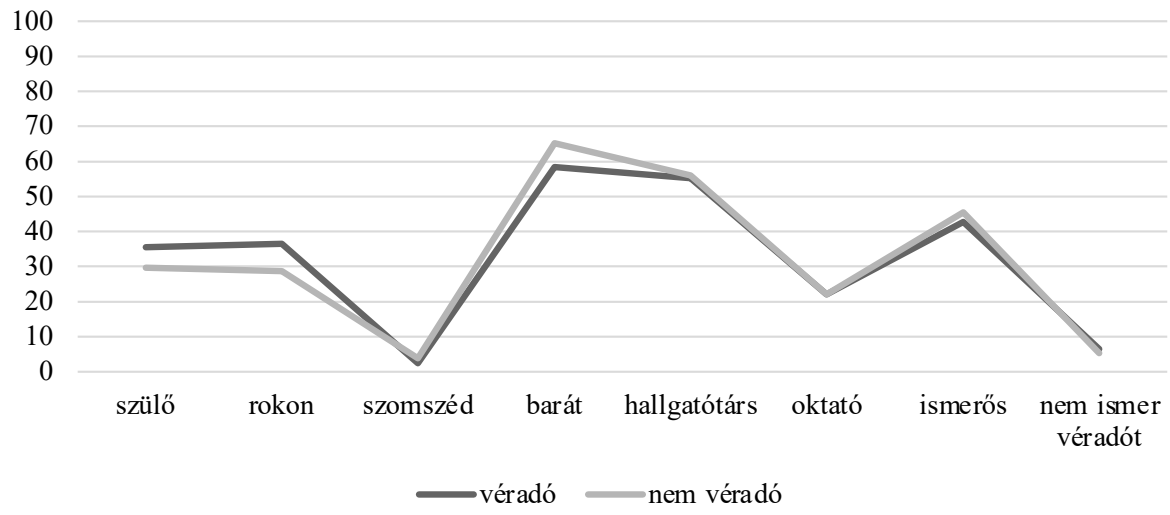

Megjegyzés: Az összekötött vonal a profil szemléltetésére szolgál.

Forrás: saját szerkesztés 
A véradó személyektől ( $\mathrm{N}=250)$ megkérdeztük, hogy az őket körülvevő társas térben kik voltak azok, akik hatottak arra, hogy elkezdjenek vért adni. Ahogy a 2. ábrán olvasható, a szülők és barátok ez irányú hatása kiemelkedő, emellett pedig az olyan személyek hatása tünik meghatározónak, akik már korábban adtak vért, ezért meggyőzően érvelhetnek a véradás fontossága, a véradástól való félelmek legyőzhetősége mellett. Erős meggyőző erővel bírhat a véradás elkezdésére irányuló döntésre, ha egy korábban vérkészítményre szoruló beteg beszámolójáról értesül a személy. Kisebb mértékben, de az egészségügyi szakemberek (pl. orvosok) ez irányú szerepe is kimutatható, ami azért fontos, mert az ápolók mellett az orvosok hatása a legfontosabb a véradás egészségügyi hatásainak ismertetése, esetleges epidemiológiai (pl. megfertőződéstől) vagy fiziológiai eredetű (pl. rosszulléttől) félelmekre adható válaszok kapcsán.

2. ábra: A véradás elkezdésére hatást gyakorló személyek $(\mathrm{N}=250)$

Figure 2. Persons influencing the decision to becoming a blood donor $(\mathbf{N}=\mathbf{2 5 0})$

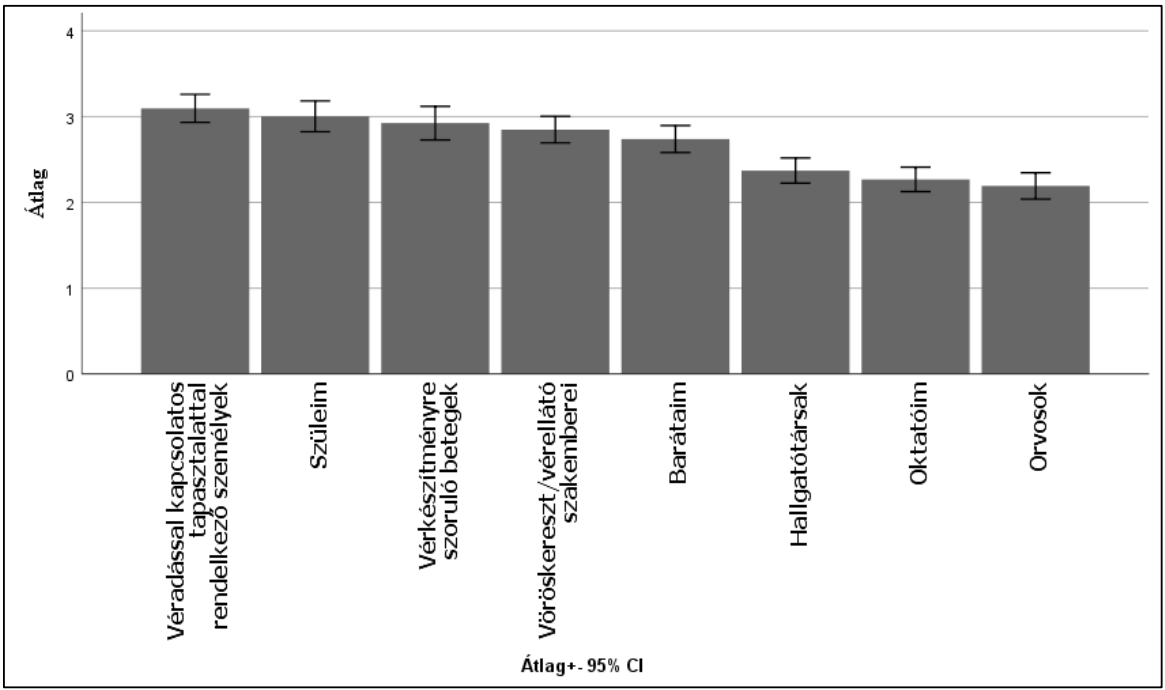

Forrás: saját szerkesztés 
A véradással kapcsolatos ismeretek

Information about blood donation

Megvizsgáltuk, találunk-e különbségeket a donorok és nem donorok között a véradással kapcsolatos főbb információk megléte kapcsán. Ahogy a 3. ábrán látható, egy kivétellel (,a vérátömlesztés csak véradóktól nyerhetö") minden kérdésre jobban tudják a választ a véradók. Azt, hogy a levett vér mennyisége $450 \mathrm{ml}$, a véradók szignifikánsan jobban ismerték ( $\mathrm{t} 510=8,795 ; \mathrm{p}<.001)$. Szignifikáns különbség volt kimutatható a véradók javára a véradás alsó és felső korhatárának (18-65 év) ismerete ( $\mathrm{t} 510=3,842 ; \mathrm{p}<.001)$, a véradásért járó étkezési jegy $(\mathrm{t} 510=12,388 ; \mathrm{p}<.001)$, a véradást megelőző orvosi vizsgálat szükségessége (t510=5,80;p<.001), az ideiglenes kizárás kritériumai ( $\mathrm{t} 510=6,023$; $\mathrm{p}<.001), \quad \mathrm{a}$ folyadékfogyasztás szükségessége (t510=5,188; $\mathrm{p}<.001)$, a két véradás között eltelt idő (56 nap) tekintetében ( $\mathrm{t} 510=7,742 ; \mathrm{p}<.001)$. Szignifikánsan jobban ismerték a véradók azt az összefüggést is, hogy a menstruáció nem feltétlenül kizáró ok a véradásból (t510=1,963; p<.001). Egyes tudnivalókat ( $\mathrm{pl}$. a vérátömlesztés csak donorok segítségével lehetséges), mind a donorok, mind a nem donorok nagy százaléka nem ismerte, ami felhívja a figyelmet az információs kampányok országos és regionális szinteken történő alkalmazásának szükségességére.

\section{3. ábra: A véradással kapcsolatos ismeretekkel tisztában levő személyek aránya (\%) $(\mathrm{N}=512)$ \\ Figure 3. Knowledge of information about blood donation \\ (\% of respondents who answered correctly to each question) $(\mathrm{N}=512)$}

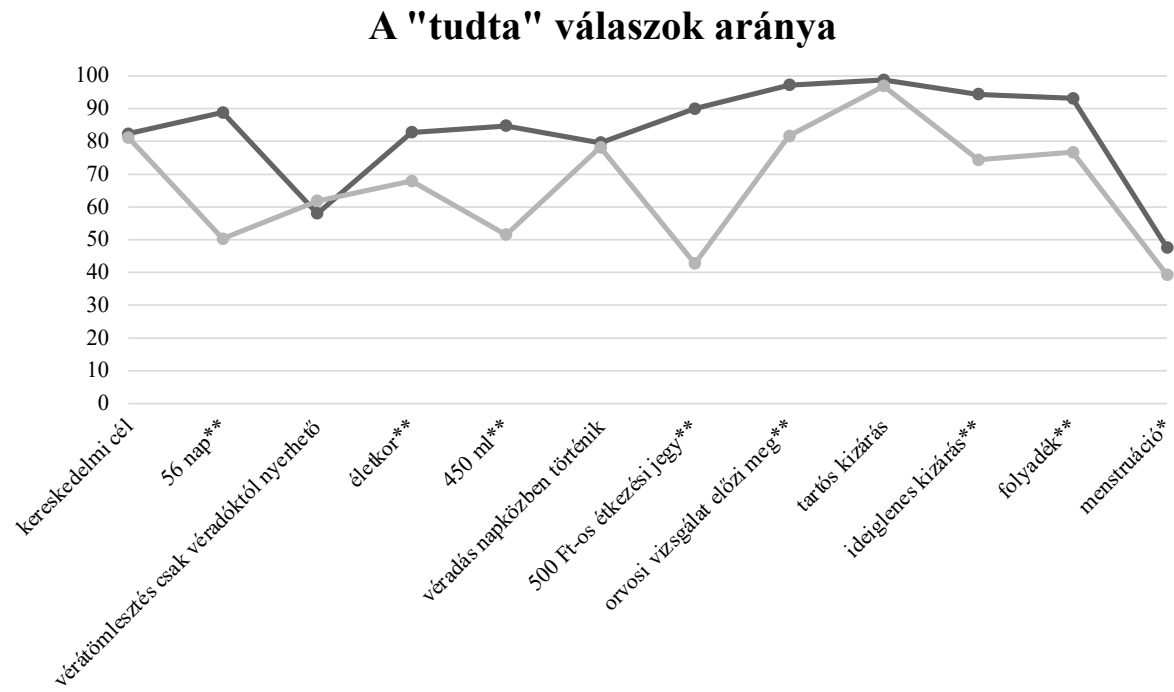

Megjegyzés: ${ }^{*} p<.01 ;{ }^{*} p<.05$, Az összekötött vonal a profil szemléltetésére szolgál.

Forrás: saját szerkesztés 
A véradás kommunikációs-és médiamegjelenése The representation of blood donation in the media and other forums

Rákérdeztünk arra is, hogy milyen gyakran találkoznak a hallgatók a véradás témájával a különböző kommunikációs csatornákon. Ahogy a válaszokból látszik (4. ábra), az internet elsődleges információforrásnak tekinthető, leginkább a véradással kapcsolatos honlapokat és a közösségi oldalak véradó eseményeit emelhetjük ki. A plakátok, prospektusok hatása napjainkban is jelentős (pl. faliújság), de a közvetlen ismerősöktől is átlagban havonta értesülnek a véradással kapcsolatos információkról. A televízióban és a rádióban - annak ellenére, hogy a donorok tömeges elérésének potenciálját rejti
- ritkábban mint havonta találkoznak a hallgatók ezzel a témával. A tanulmányi rendszerek szerepe - a benne rejlő lehetőségek ellenére - hasonlóan korlátozottnak tünik a véradással kapcsolatos információk megszerzésében. A véradók és a nem véradók közötti különbségeket összehasonlítva azt láthatjuk, hogy amíg a tanulmányi rendszerben szignifikánsan gyakrabban találkoznak ez irányú információkkal a nem véradók (t509=3,295; $\mathrm{p}<.001$ ), addig honlapokon (t509=-6,841; $<<.001$ ), közösségi oldalakon ( $\mathrm{t} 509=-2,632 ; \mathrm{p}<.05)$ gyakrabban olvasnak ilyen üzeneteket a véradók, rövid szöveges üzeneteket is gyakrabban kapnak ezzel kapcsolatban ( $\mathrm{t} 509=-8,038 ; \mathrm{p}<.001)$, míg a többi kommunikációs platform tekintetében nem találunk szignifikáns különbséget a két csoport között.

\section{4. ábra: A véradással kapcsolatos információk elérhetősége a különböző médiumokban ( $\mathrm{N}=512)$ Figure 4. Availability of the information about blood donation in the different media platforms $(\mathrm{N}=512)$}

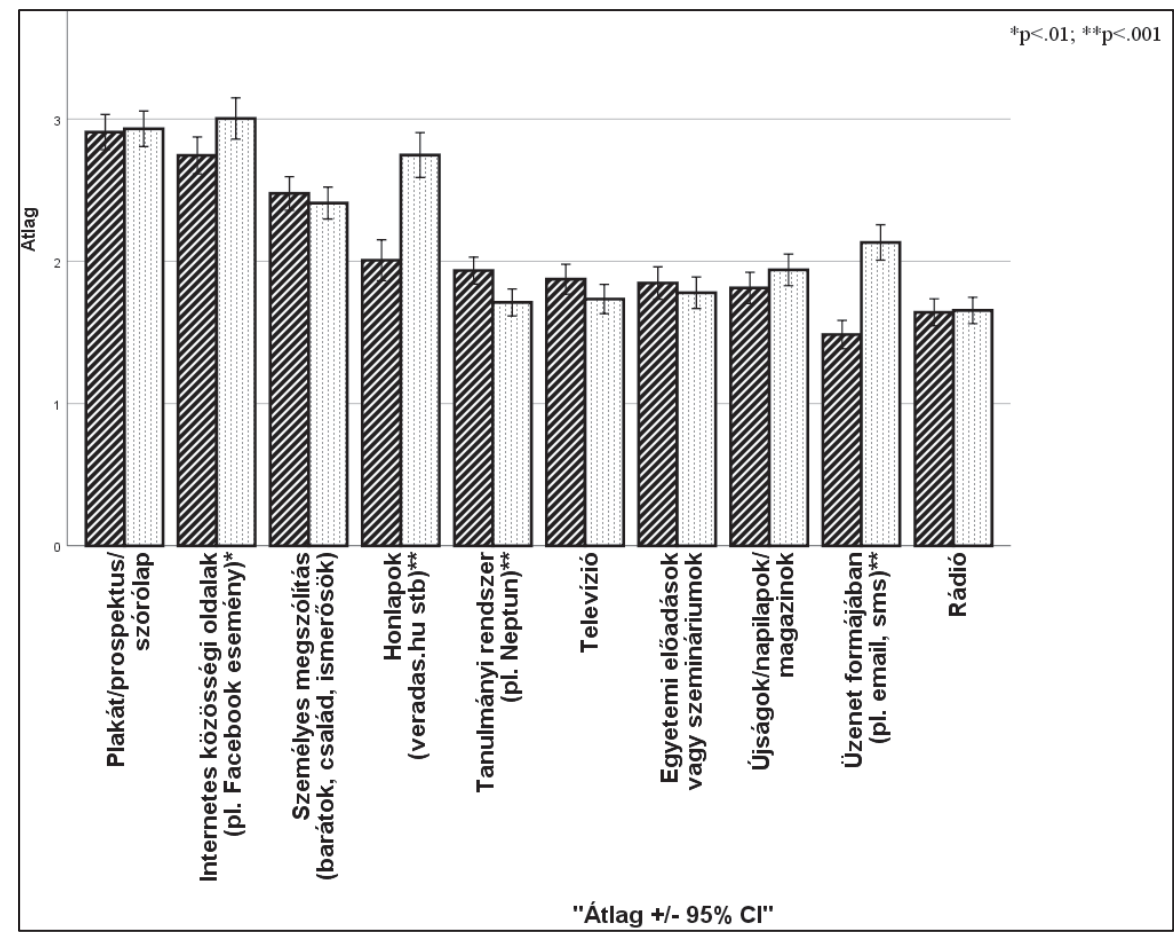

Forrás: saját szerkesztés 
A következő kérdés arra irányult, hogy véleménye szerint mennyire hatékonyan szólítják meg a kitöltőt a különböző kommunikációs csatornák. Ahogy az 5. ábrán látható, az internetet nevezték meg a leghatékonyabbnak, de az aktív véradók, illetve korábban már vérkészítményre szoruló ismerősök meggyőző erejét is jelentős tényezőként említették. Érdekesség, hogy míg az internet $\left(\mathrm{t}_{509}=\right.$ 3,$003 ; \mathrm{p}<.05$ ), valamint a vérellátóban dolgozó sze- mélyek által tartott elóadások $\left(\mathrm{t}_{509}=-2,644 ; \mathrm{p}<.05\right) \mathrm{a}$ véradók szerint hatékonyabbak, addig a tanulmányi rendszer $\left(\mathrm{t}_{509}=2,546 ; \mathrm{p}<.05\right)$ a nem véradók szerint bizonyul hatékonyabbnak. Valószínüsíthetjük, hogy a nem véradók számára kevéssé ismertek olyan, véradással kapcsolatos platformok, mint a veradas. hu, ezért a tanulmányi rendszer ez irányú értesítései számukra nagyobb hozzáadott értékkel bírhatnak.

5. ábra: A különböző kommunikációs csatornák észlelt hatékonysága a megszólítás terén $(\mathrm{N}=512)$ Figure 5. Perceived efficacy of the different communication channels related to blood donation $(\mathrm{N}=512)$

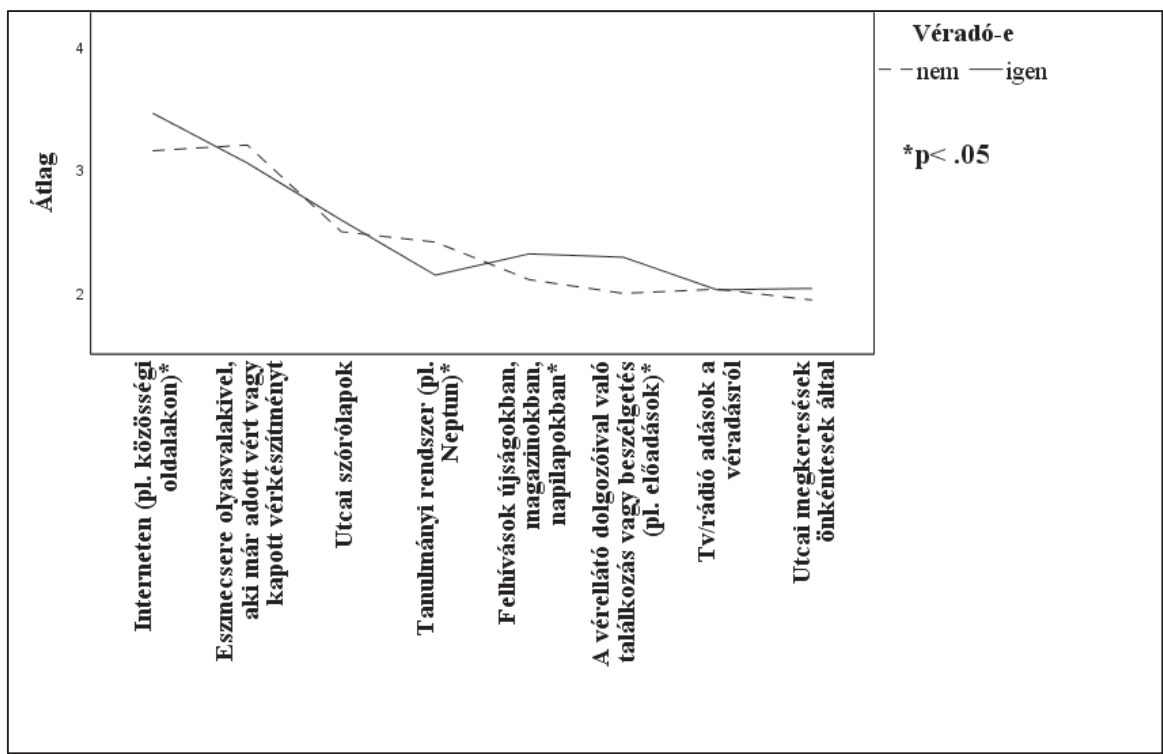

Megjegyzés: Az összekötött vonal a profil szemléltetésére szolgál.

Forrás: saját szerkesztés 
A véradó kampányok megtervezése szempontjából érdemes tisztában lenni azzal, milyen típusú kommunikációs üzeneteket látnak hatékonynak kitöltőink a hallgatótársaik megszólítása szempontjából. Ahogy a 6. ábrán látható, egy gondolkodásra késztető szlogen, egy ismert személy megnyerése egy arculati kampányhoz, személyes példamutatással élő ismert személy, hallgatótárs vagy oktató, valamint az erős és felkavaró képek használata mind a véradóknál, mind a nem véradóknál magas értékelést kapott. A reklámkampány elemek közül a szlogeneket (t507=-3,359; p<.001), az ismert személy arcának felhasználását ( $\mathrm{t} 507=-2,327 ; \mathrm{p}<.05)$, a személyes példamutatással élő ismert személyt (t507=-4,051; $\mathrm{p}<.001), \quad$ hallgatót $\quad(\mathrm{t} 507=-3,137$; $\mathrm{p}<.05$ ) és oktatót ( $\mathrm{t} 507=-2,498 ; \mathrm{p}<.05)$, a mesterséges beállítású képeket (boldogan pózoló véradók) (t507=-3,417; p<.001) és a mesehősök, képregényhősök alkalmazását (t507=-2,757; p<.05) a véradók szignifikánsan nagyobb hatékonyságúnak ítélik meg hallgatótársaik megszólításában, mint nem véradó társaik. Az erős képek használatában (t507=-.098; p>.05) és a vonzó személyekről készült fotók használatában ugyanakkor nem találhatunk szignifikáns különbséget (t507=-.879; p>.05), és ennek észlelt megszólító ereje általában is alacsonyabb, mint a többi üzenettípusé.

6. ábra: A különböző reklámkampány elemek megszólító ereje a hallgatótársak körében ( $\mathrm{N}=512)$

Figure 6. Perceived efficacy of different advertisement campaign elements addressing student peers $(\mathrm{N}=512)$

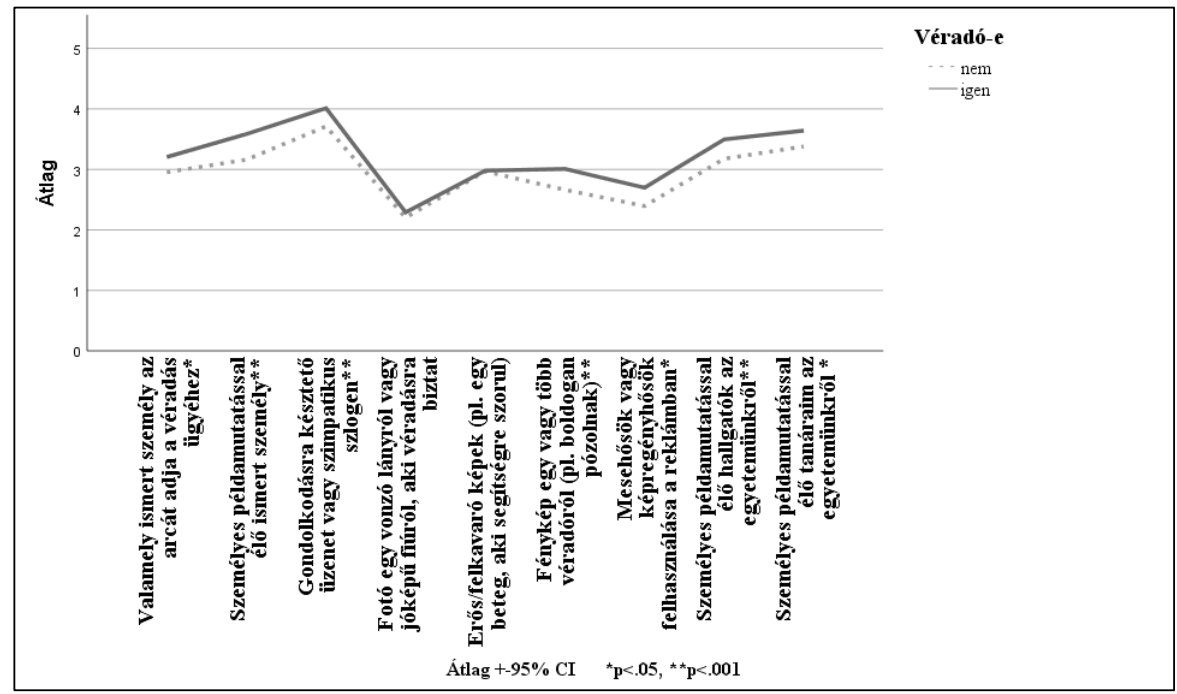

Megjegyzés: Az összekötött vonal a profil szemléltetésére szolgál.

Forrás: saját szerkesztés 
A véradóvá válás lehetséges katalizátorai

Factors leading to becoming a donor

Fontosnak tartottuk arra is rákérdezni, mi segítene a jelenleg nem véradó személyeknek abban, hogy donorrá váljanak. A 7. ábrán látható, hogy a nem véradók számára fontos segítséget jelentene, ha minden szükséges információt érthető formában megkapnának a véradást megelözően, ami eloszlathatná véradással kapcsolatos kételyeiket, információhiányból eredő félelmeiket (kognitív bizonytalanság csökkentése). Emellett az is segítene, ha valaki elkísérné öket a véradásra, és együtt adhatnának vért (társas támogatottság érzése). Ez utóbbi informatív lehet a véradó kampányok számára is (pl. „Közösen vért adni menő”). Hazánkban is fontos tényező a könnyen elérhető véradási helyszín. Bár a véradást alapvetően segíti a nyugodt klíma, és minél alacsonyabb a szorongás, annál kisebb a rosszullét esélye, számolnunk kell azzal, hogy nem minden munkahely tolerálja egyenlö mértékben a véradás miatti távolmaradást, még ha ezt törvényi háttér alapján figyelembe kellene is vennie. A donorbarát ügyfélszolgálat ugyancsak magas vonzerővel bír, mely egyértelmủen a nyitott, problémaérzékeny, türelmes szakemberi attitüd jelentöségét hangsúlyozza. A véradási helyszín előzetes felkeresése közepes mértékben segítené a véradásra irányuló döntést.

7. ábra: A véradásra irányuló döntést segítő tényezők nem véradók körében $(\mathrm{N}=262)$

Figure 7. Potential factors influencing the decision to give blood among non-blood donors $(\mathrm{N}=\mathbf{2 6 2})$

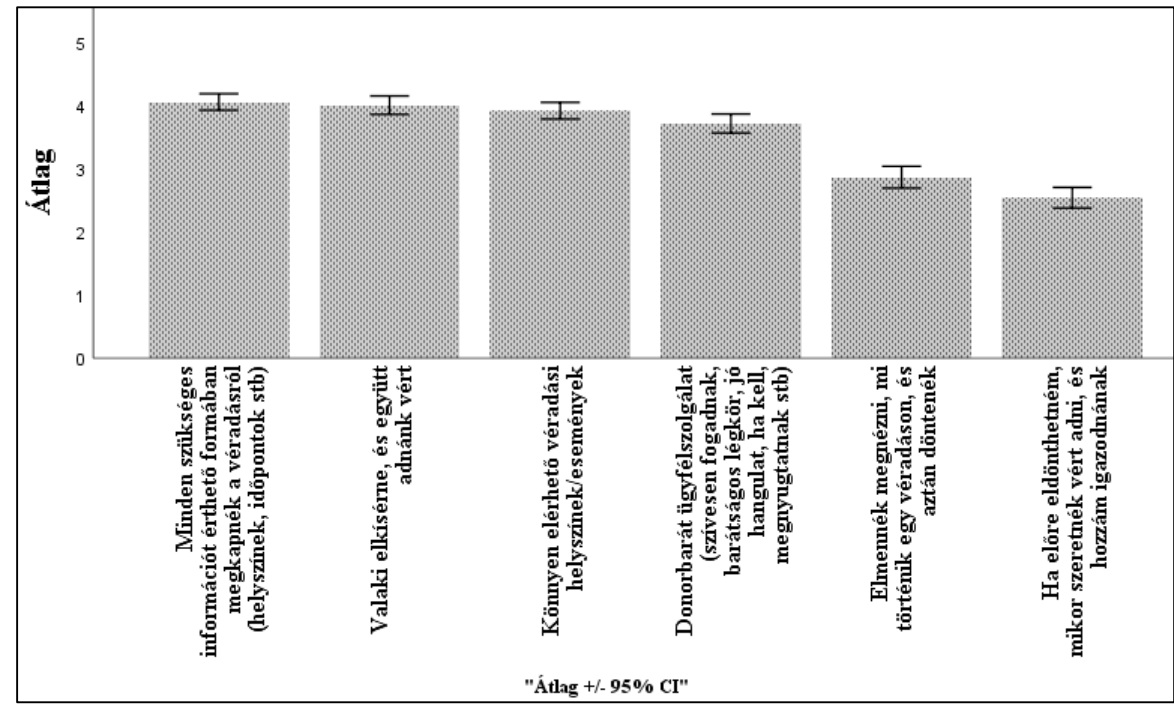

Forrás: saját szerkesztés 
Végül arra is rákérdeztünk, milyen típusú információk hasznosak a hallgatók számára. A 8. ábrán láthatjuk, hogy a véradók számára a legfontosabb információ, hogy hol és mikor lesz a véradás, szignifikánsan fontosabb, mint a nem véradók számára $\left(\mathrm{t}_{507}=-4,425 ; \mathrm{p}<.001\right)$. Ezzel összefüggésben azt is fontosabbnak tartják tudni, hogy a felsőoktatási intézményben lesz-e a véradás $\left(\mathrm{t}_{507}=-4,425\right.$; $\mathrm{p}<.001$ ), ami informatív lehet az intézmények véradással foglalkozó szakemberei számára. Szintén fontosabb a véradók számára (de nem szignifikánsan), hogy milyen ajándékokat, elismerést, köszö- netnyilvánítást kapnak majd a véradást követően. A két csoport számára ugyanolyan fontossággal bír, hogy ha kizárásra kerülnek, részletesen mondják el nekik az okokat. A nem véradók számára szignifikánsan nagyobb fontossággal bírnak az azzal kapcsolatos ismeretek, hogy mennyire biztonságos a véradás $\left(\mathrm{t}_{507}=4,521 ; \mathrm{p}<.001\right)$, mit éreznek más véradók donáció közben $\left(\mathrm{t}_{507}=5,954 ; \mathrm{p}<.001\right)$, hogyan hasznosul a vér később $\left(\mathrm{t}_{507}=2,689 ; \mathrm{p}<.001\right)$, illetve pontos és részletes információk arról, hogy mi fog történni a véradáson $\left(\mathrm{t}_{507}=5,689 ; \mathrm{p}<.001\right)$.

8. ábra: A különböző véradással kapcsolatos információk észlelt hasznossága $(\mathrm{N}=512)$

Table 8. Perceived efficacy of the different kinds of information about blood donation $(\mathrm{N}=512)$

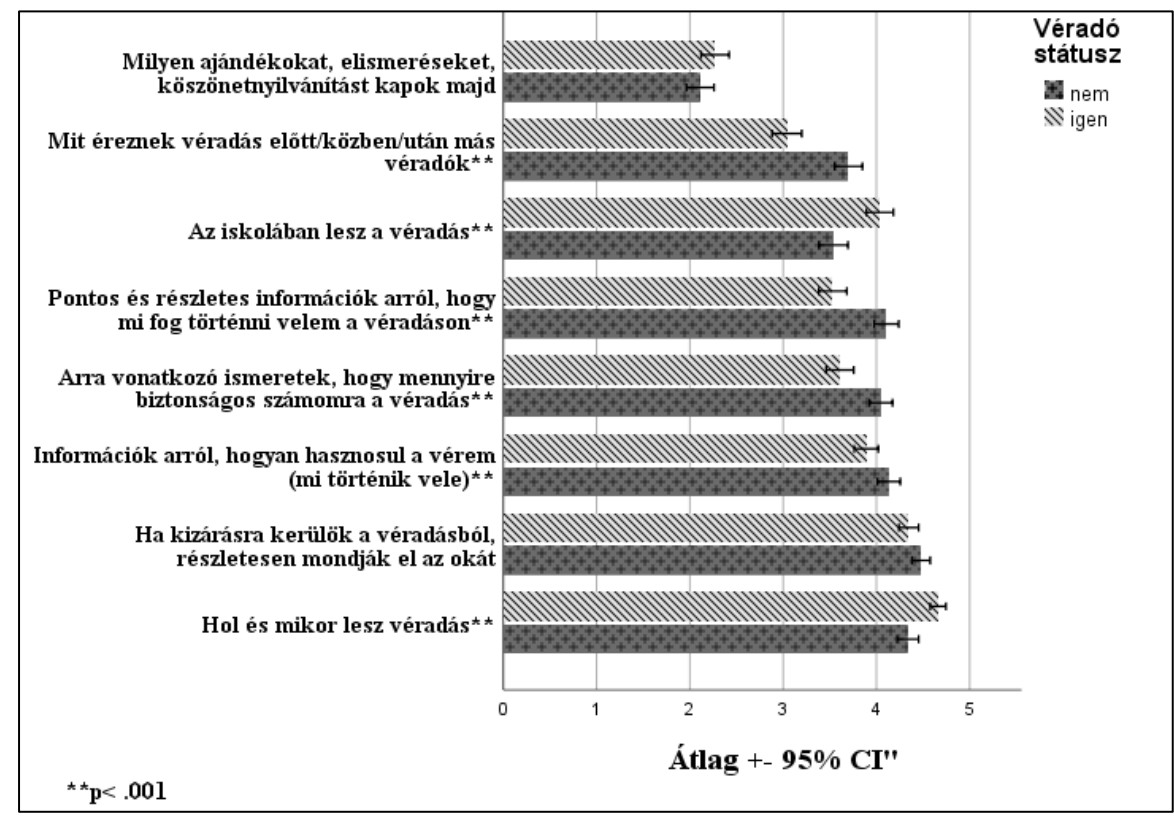

Forrás: saját szerkesztés 


\section{ÖSSZEGZÉS ÉS JAVASLATOK SUMMARY AND RECOMMEN- DATIONS}

Az első hipotézisünk (H1) nem teljesült, mivel a véradók és a nem véradók között nem találtunk szignifikáns különbséget a véradó szülök és a barátok számát tekintve. Igazoltnak tekinthetők viszont azok a hipotéziseink, miszerint a véradással kapcsolatos ismereteknek inkább birtokában vannak a véradók (H2), hogy a véradással kapcsolatos információk a leghatékonyabban az interneten jutnak el a véradókhoz (H4), illetve, hogy a véradással kapcsolatos ismeretek és a társas támogatás a nem véradók számára nagy segítséget jelentenek $(\mathrm{H} 3)$.

Eredményeink alapján kiemelhetjük, hogy a szülők és a barátok, a munka- és iskolatársak, valamint az aktív véradók bevonása a toborzásba kulcstényezőnek tekinthetők (Piersma és Merz 2019); hogy a véradáshoz kapcsolódó szakemberek rugalmassága, szakmai tudása és hitelessége nagymértékben hozzájárulhat a donorok toborzásához és megtartásához.

$\mathrm{Az}$ egyetemi előadásokon, szemináriumokon elvétve esik szó a véradásról, így fontos lenne véradás iránt elkötelezett oktatók bevonása a toborzásba (pl. rövid, a véradás folyamatát, a vér útját bemutató prezentációk levetítése a félév elején a diákoknak, ezzel csökkentve az információhiányból eredő távolmaradást).

Egyes kérdéskörök (a véradás feltételei, az ideiglenes és tartós kizárás kritériumai) mentén hiányos ismeretekkel találkozunk, föleg a nem véradóknál. Ezek orvoslása csökkenthetné a véradásra alkalmas és a ténylegesen véradó személyek számában mutatkozó jelentős különbséget (Heinrich 1999). Merz et al. (2018) kiemelték, hogy azok a donorok, akik a véradó karrier kezdetén jelezték, hogy információkat szeretnének kapni a transzfúziós folyamatról (pl. a vérkészítmények feldolgozása, hogyan hatott mindez a betegekre) kisebb eséllyel hagyták abba saját elhatározásból a véradást a későbbiekben. Ezt feltehetően az magyarázza, hogy amikor egy tevékenység ismeretlen a személy számára, a folyamatról való információ némi kontrollérzést biztosít, ami csökkentheti a szorongást (Ferguson 2004).

Mivel a véradástól való távolmaradás hátterében a hiányos marketingkommunikáció is kimutatható (Bednall \& Bove 2011, Muthivni et al. 2015), a kommunikációs kampányokban hasznos lenne bemutatni a véradással kapcsolatos ismereteket (milyen gyógyszerkészítmények szedése jelent kizárást, melyek mellett lehetséges vért adni, a sze- dés után mennyi idővel lehet jelentkezni véradásra, az 50 kg-os testtömeg-határ oka stb). A már meglévő honlapok (pl. veradas.hu) ismertebbé tétele is jelentős potenciállal bír. Korábbi kutatások (Mathew et $a l$. 2007) résztvevői még a televízió és rádió megygyőzésben betöltött vezető szerepét hangsúlyozták, melyek helyét mára az elektronikus média vette át: a leghatékonyabb kommunikációs csatornáknak ma a közösségi oldalak, honlapok, sms-ek és a plakátok tekinthetők, továbbá a személyes ismerősök hatása is jelentős a véradás elkezdésére és folytatására. A kezdetben személyesen (pl. barátok, hallgatótársak) megszólított véradók később is szívesebben adnak vért személyes megszólításra (Godin et al. 2007).

Új, innovatív, a korosztály nethasználati szokásaira és érdeklődési körére reflektáló kommunikációs kampányok (lásd pl. Walking Dead és Trónok harca kampányok sikere), és a nem véradók személyes megszólítása (pl. sms-ek küldése számukra is a véradó lehetőségekről és a véradással kapcsolatos ismeretekről) fontos szerepet tölthetnek be a jövő véradóinak megszólításában.

Hasznos lehetne továbbá, ha minden felsőoktatási intézmény honlapján külön fül foglalkozna a véradással kapcsolatos ismeretekkel, a félév véradásainak helyszíneivel, illetve ha az intézmények a véradást követően pozitív visszajelzés (pl. sms) formájában köszönnék meg, hogy hallgatójuk fontos társadalmi hozzájárulást tett. Ez azért is fontos, mert több ízben (Merz et al. 2018, Piersma et al. 2017) bizonyítást nyert, hogy a véradással kapcsolatos pozitív attitüdök és a véradásra irányuló szándék gyakran megakadályozzák a lemorzsolódást. 


\section{KORLÁTOK ÉS KITEKINTÉS LIMITATIONS AND FUTURE DIRECTIONS}

Kutatásunk eredményeinek felhasználása a kommunikációs kampányok tervezése során fontos szerepet tölthet be a toborzás hatékonyságának növelése, illetve a többszörös véradók megtartása érdekében. Kutatásunk újdonságértéke, hogy véradó és nem véradó személyek tapasztalatait egyaránt vizsgálat tárgyáva tette, ugyanakkor korlátjának tekinthető, hogy csak felsőoktatási hallgatók mintáján vizsgáltuk a véradás kommunikációs- és médiareprezentációját. Terveink között szerepel a már meglévő, valamint egyes lehetséges jövőbeli kommunikációs kampányokkal kapcsolatos értékelő viszonyulások felmérése is, különös tekintettel a nemzetközi szervezetek ide vonatkozó jó gyakorlatainak hazai adaptációjára.

\section{HIVATKOZÁSOK REFERENCES}

Abbasi, R. A., Maqbool, O., Mushtaq, M., Aljohani, N. R., Daud, A., Alowibdi, J. S. \& Shahzad, B. (2018), "Saving lives using social media: Analysis of the role of twitter for personal blood donation requests and dissemination", Telematics and Informatics, 35(4), 892-912 DOI: 10.1016/j.tele.2017.01.010

Abril, E. (2016), "Explaining Voluntary Blood Donation from a Communication Perspective", Cuadernos.info, 38, 17-33 DOI: 10.7764/ cdi.38.697

Agrawal, A., Tiwari, A. K., Ahuja, A. \& Kalra, R. (2013), "Knowledge, attitude and practices of people towards voluntary blood donation in Uttarakhand", Asian Journal of Transfusion Science, 7(1), 59-62 DOI: 10.4103/09736247.106740

Al-Drees, A. M. (2008), "Attitude, belief and knowledge about blood donation and transfusion in Saudi population", Pakistan Journal of Medical Sciences, 24(1), 74

Alessandrini, M. (2007), "Community volunteerism and blood donation: Altruism as a lifestyle choice", Transfusion Medicine Reviews, 21(4), 307-316 DOI: 10.1016/j.tmrv.2007.05.006

Bednall, T. C. \& Bove, L. L. (2011), "Donating blood: a meta-analytic review of self-reported motivators and deterrents", Transfusion Medicine Reviews, 25(4), 317-334 DOI: 10.1016/j. tmrv.2011.04.005

Béla-Csovcsics, A. \& Kincsesné, B. V. (2018), „Véradó vagyok. De miért? Egyetemisták véradási szokásait befolyásoló pszichológiai és személyes tényezők vizsgálata", Marketing \& Menedzsment, 52(3-4), 61-71

Bettinghaus, E. P., \& Milkovich, M. B. (1975), "Donors and Nondonors: Communication and Information", Transfusion, 15(2), 165-169 DOI: 10.1046/j.1537-2995.1975.15275122813.x

Dadwani, R. S., Joshi, K., Joshi, K. \& Kartha, G. (2019), "A Study on Knowledge, Attitude and Practice on Blood Donation among First Year Undergraduate Students", International Journal of Preventive, Curative \& Community Medicine, 5(2), 4-9 DOI: $10.24321 / 2454.325 x .201908$

Ferguson, E. (2004), "Conscientiousness, emotional stability, perceived control and the frequency, recency, rate and years of blood donor behaviour", British Journal of Health Psychology, 9(3), 293-314 DOI: 10.1348/1359107041557011

France, C. R., France, J. L., Kowalsky, J. M., \& Cornett, T. L. (2010), Education in donation 
coping strategies encourages individuals to give blood: further evaluation of a donor recruitment brochure. Transfusion, 50(1), 85-91 DOI: 10.1111/j.1537-2995.2009.02381.x

Germain, M. \& Godin, G. (2016), “The relative efficacy of telephone and email reminders to elicit blood donation", Vox Sanguinis, 110(3), 278-281 DOI:10.1111/vox.12316

Gillespie, T.W. \& Hillyer, Ch.D. (2006), "Blood donors and factors impacting the blood donation decision", Transfusion Medicine Reviews, 16(2), 115-130 DOI: 10.1053/tmrv.2002.31461

Godin, G., Conner, M., Sheeran, P., BélangerGravel, A. \& Germain, M. (2007), +Determinants of repeated blood donation among new and experienced blood donors", Transfusion, 47(9), 1607-1615 DOI: 10.1111/j.15372995.2007.01331.x

Godin, G., Vézina-Im, L., Bélanger-Gravel, A. \& Amireault, S. (2011), "Efficacy of interventions promoting blood donation: A systematic review", Transfusion Medicine Reviews, 26(3), 224-237 DOI: 10.1016/j.tmrv.2011.10.001

Heinrich J. (1999), Blood supply: availability of blood to meet the nation's requirements. HEHS99-187R. Washington (DC): General Accounting Office (GAO), Health, Education and Human Services Division

Masser, B., France, C. R., Foot, J., Rozsa, A., Hayman, J., Waller, D., \& Hunder, E. (2016), "Improving first-time donor attendance rates through the use of enhanced donor preparation materials", Transfusion, 56(6pt2), 1628-1635 DOI: $10.1111 / \operatorname{trf} .13496$

Mathew, S. M., King, M. R., Glynn, S. A., Dietz, S. K., Caswell, S. L., \& Schreiber, G. B. (2007), "Opinions about donating blood among those who never gave and those who stopped: a focus group assessment", Transfusion, 47(4), 729-735 DOI: 10.1111/j.1537-2995.2007.01177.x

Merz, E. M., Ferguson, E., \& van Dongen, A. (2018), "Psychosocial characteristics of blood donors influence their voluntary nonmedical lapse", Transfusion, 58(11), 2596-2603 DOI: $10.1111 /$ trf. 14891

Misje, A. H., Bosnes, V., Gåsdal, O., \& Heier, H. E. (2005), "Motivation, recruitment and retention of voluntary non-remunerated blood donors: a survey-based questionnaire study", Vox Sanguinis, 89(4), 236-244 DOI: 10.1111/j.14230410.2005.00706.x

Moore, M. B., Gitau, T., \& Kerochi, A. (2020), "Factors influencing blood donation practices among students of private universities in Thika Town, Kiambu County, Kenya", International Journal of Community Medicine and Public Health, 7(6), 2090 DOI: 10.18203/2394-6040. ijcmph20202457

Muthivhi, T. N., Olmsted, M. G., Park, H., Sha, M., Raju, V., Mokoena, T., ... \& Reddy, R. (2015), "Motivators and deterrents to blood donation among Black South Africans: a qualitative analysis of focus group data", Transfusion Medicine, 25(4), 249-258 DOI: 10.1111/tme.12218

Nilsson Sojka, B. \& Sojka, P. (2007), "The blood donation experience: Self-reported motives and obstacles for donating blood", Vox Sanguinis, 94(1), 56-63 DOI: 10.1111/j.14230410.2007.00990.x

Piersma, T. W., \& Merz, E. M. (2019), “(Non-) donor demographics, donation willingness, and the donor career", Transfusion, 59(6), 18941896 DOI: $10.1111 /$ trf. 15268

Piersma, T. W., Bekkers, R., Klinkenberg, E. F., De Kort, W. L., \& Merz, E. M. (2017), "Individual, contextual and network characteristics of blood donors and non-donors: a systematic review of recent literature", Blood Transfusion, 15(5), 382

Quéniart, A. (2013), "Blood donation within the family: the transmission of values and practices", Transfusion, 53, 151S-156S DOI:10.1111/trf.12474

Rojas, H. \& Puig-i-Abril, E. (2006), "Comunicación y donación voluntaria de sangre [Communication and voluntary blood donation]", Journal of the Iberian-American Group of Transfusion Medicine, 22, 8-20.

Royse, D., \& Doochin, K. E. (1995), "Multi-gallon blood donors: who are they?" Transfusion, 35(10), 826-831 doi:10.1046/j.15372995.1995.351096026363.x

Sümnig, A., Feig, M., Greinacher, A., \& Thiele, T. (2018), "The role of social media for blood donor motivation and recruitment" Transfusion, 58(10), 2257-2259 DOI:10.1111/trf.14823

Tadesse, W., Ayalew, Y., Yisma, E., Liben, M. L., \& Wudu, M. (2018), "Knowledge, Attitude, Practice and Associated Factors towards Voluntary Blood Donation among Regular Health Science Students of Samara University, Ethiopia", Health Science Journal, 12(1) DOI: $10.21767 / 1791-809 x .1000542$

Titmuss, R. (1970), The gift relationship: From human blood to social. Policy, London

Wakefield, M. A., Loken, B., \& Hornik, R. C. (2010), "Use of mass media campaigns to change health behaviour", The Lancet, 376, 1261-1271 DOI: 10.1016/s0140-6736(10)60809-4

Zito, E., Alfieri, S., Marconi, M., Saturni, V., \& Cremonesi, G. (2012), “Adolescents and blood donation: motivations, hurdles and possible recruitment strategies", Blood Transfusion, 10(1), 45 DOI: 10.1111/j.17512824.2012.01590.x 
Dorner László, tanársegéd dorner.laszlo@uni-eszterhazy.hu

Eszterházy Károly Egyetem

\section{Empirical study of the media representation of voluntary blood donation in Hungary on a sample of university students}

\section{THE AIMS OF THE PAPER}

To examine the communication and media representation of voluntary blood donation: on which platforms and how often are university students exposed to information on the topic, how effectively do current recruitment methods, platforms, advertisements, and people with significant impact on candidates' lives address the potential blood donors. In addition, general information about blood donation was also the subject of our study.

\section{METHODOLOGY}

Blood donor $(\mathrm{N}=250)$ and non-blood donor $(\mathrm{N}=262)$ students in higher education participated in our study and completed self-administered questionnaires adapted from previous international research (eg. Zito et al 2012) and self-designed questionnaires.

\section{MOST IMPORTANT RESULTS}

Social contacts are of paramount importance in addressing both blood donors and non-blood donors: in addition to parents and friends, we can highlight the role of active blood donors in recruitment. Printed promotional materials and social networking services play a key role in informing the potential donors, and personal role models and persuasive slogans can be highlighted as most efficient elements of an advertising campaign. Accurate information (about the conditions and process of blood donation and the reasons for exclusion), the communication skills and empathy of the staff and a convenient donation site might contribute to starting a donor career.

\section{RECOMMENDATIONS}

Increasing the role of active blood donors in recruitment, applying a dynamic marketing and communication strategy tailored to the needs of young adults, relying mainly on the digital platforms, and ensuring a continuous flow of information can improve the effectiveness of target group recruitment and retention.

Keywords: voluntary blood donation, media representation, communication, marketing, internet 